\title{
The Effect of the Photon Radiation in the Microbicidal Effect of Transient Electric Arcs in Aqueous Systems
}

\author{
By L. EDEBO \\ Institute of Medical Microbiology, University of Uppsala, Uppsala, Sweden \\ (Accepted for publication 20 July 1967)
}

SUMMARY

The importance of photon radiation for the microbicidal effect of electrical discharges in water has appeared from a series of experiments. (a) An ultraviolet (u.v.)-sensitive strain of Escherichia coli was more susceptible to discharges than a u.v.-resistant mutant derived from it. (b) The kinetics of the inactivation by discharges were under certain conditions similar to those of continuous u.v. irradiation. (c) Addition of u.v.-absorbing substances to the discharge liquid decreased the bactericidal efficiency of the discharges to an extent which paralleled the u.v. absorbance. $(d)$ The bactericidal effect decreased as the distance from the spark increased. (e) Bacteria enclosed in a cellophan bag were killed by discharges outside the bag, even when the bag was kept in the air above the discharge liquid. $(f)$ Also discharges in air were active. $(g)$ Bacteria inactivated by discharges were accessible to photoreactivation, but the magnitude of the reactivation was generally less than that obtained with bacteria inactivated by continuous u.v.-irradiation. In addition to direct radiation effects other kinds of microbicidal activities were produced by the electric discharges.

\section{INTRODUCTION}

Submerged electrical discharges in water have a potent microbicidal effect for a wide range of micro-organisms (Brandt et al. 1962; Allen \& Sioke, 1966). The physicochemical effect of the discharges consists of, amongst others, ionization, heat, a pressure shock wave, radiation, and chemical effects. Previous experiments (Edebo \& Selin, 1968) showed that the microbicidal effect of the pressure shock wave was insignificant, nor could any of the main electrical quantities be correlated with the killing effect. However, a microbial suspension enclosed in a dialysis bag was inactivated by discharges, unless it was shielded from the electric arc (Edebo \& Selin, I968). These results indicated that radiation from the arc might be essential for the microbicidal effect.

\section{METHODS}

The Escherichia coli B strains B I5 (u.v.-sensitive) and B I7 (u.v.-resistant) were obtained from Dr G. Bertani, Department of Microbial Genetics, Karolinska Institutet, Stockholm.

The electrical equipment, cultivation of micro-organisms and colony counts were made as described previously (Edebo \& Selin, 1968). When the killing effect in free suspensions in the discharge vessel (fig. 2 of Edebo \& Selin, 1968) was investigated, each value was calculated as the arithmetic mean of three individual determinations. 
The difference between each one did not usually exceed $30 \%$. In some experiments suspensions of bacteria were enclosed in four separate cellophan bags, fastened to a metal frame and placed in the discharge vessel. Discharges were made and then samples taken from the cellophan bags by means of a syringe and needle. The spread of colony count values was greater in these cases, sometimes, particularly at high killing effects, the largest value being nearly 9 times the smallest. Therefore each such experiment was calculated as the geometric mean of the four individual determinations.

After treatment with discharges or continuous u.v. irradiation $3 \mathrm{ml}$. samples of the bacterial suspensions in test-tubes were subjected to visible light (Philips Attralux, $24 \mathrm{~V}$., I50 W, > 3800 A.) for photoreactivation. The samples were immersed in a water bath $\left(24^{-2} 8^{\circ}\right)$ to prevent heating, and light was admitted through $45 \times 62 \mathrm{~mm}$. windows in the wall of the container. The distance from the wall of the container to the centre of the test-tube was $90 \mathrm{~mm}$., the illumination time $30 \mathrm{~min}$.

Standard electrical arrangement (SEA): capacitance $(C)=0.6 \mu \mathrm{F}$., inductance $(L)=43 \mu \mathrm{H}$., discharge voltage $=45 \mathrm{kV}$.; electrode separation $=$ I I mm.; electrode tips consisted of copper + tungsten alloy; liquid volume in the discharge vessel $=\mathrm{I} 200 \mathrm{ml}$.

Symbols in the Figures unless otherwise stated: solid circles and continuous lines represent samples diluted $\mathrm{I} / \mathrm{IO}$ in the diluent (nutrient broth $\mathrm{r}$ g., $\mathrm{NaCl} 5 \mathrm{~g}$./1.) immediately after the discharges; open circles and broken lines those after overnight incubation in the refrigerator. Each circle is the result of one experiment from which three different samples were taken.

The characteristics of the tap water were: colour $<5 \mathrm{mg}$. Pt/1., permanganate 4-6 mg. $\mathrm{KMnO}_{4} / 1$, conductivity $354-4 \mathrm{I} 3 \mu \mathrm{mho} . / \mathrm{cm}$., pH $7 \cdot \mathrm{I}-7 \cdot 7$, total hardness calculated as $\mathrm{Ca}$ I0I-I08 mg./1.; ammonium $<0 . \mathrm{I}$, manganese $<0.05$, bicarbonate 262-286, chloride I8-2I, sulphate 26-34, nitrate 9-36, nitrite $<0.0 I$, phosphate $<0.01 \mathrm{mg}$./l. Bacteria:nutrient gelatine at $20^{\circ}$ for $48 \mathrm{~h}<\mathrm{I}$ colony/ml.; lactose broth $37^{\circ}<\mathrm{I} / 100 \mathrm{ml}$.

\section{RESULTS}

\section{Microbicidal effect of discharges with relatively high energy content $(620 J$.)}

The microbicidal effect on various concentrations of bacteria was investigated for Escherichia coli strains B I5 and B I 7 in $0.00 \mathrm{I} \mathrm{M}-\mathrm{KCl}$ and in tap water (Figs. I-4). Potassium chloride was added to distilled water, because a certain conductivity was needed to produce this type of discharge (Edebo, Holme \& Selin, unpublished results). When suspensions of $E$. coli B I 5 in $0.00 \mathrm{I} \mathrm{M}-\mathrm{KCl}$ were subjected to discharges of SEA (see methods), a large proportion of the bacteria were killed. When the logarithm of the colony count was plotted against the number of discharges, it approached a straight line (Fig. 1). The killing effect might therefore be approximately described by $S=e^{-N K}$, where $S$ is the fraction of surviving colony-forming units, $N$ is the number of discharges, and $K$ is a constant characteristic for the electrical arrangement the suspending fluid and the micro-organism investigated. For practical reasons the base Io was chosen instead of $e, S=10^{-N x}$, and the microbicidal effect of the individual discharges $(-x)$ expressed as $\log$ per discharge (l.p.d.). For suspensions of $E$. coli в I 5 whose initial colony counts were between $2 \times 10^{6}$ and $2.5 \times 10^{7}$ bacteria $/ \mathrm{ml}$. the microbicidal effect was $3 \cdot 0-2 \cdot 8$ 1.p.d. For more concentrated suspensions it became less, successively diminishing with higher bacterial concentrations. When the bacterial 
suspensions which had been subjected to discharges were left overnight in the refrigerator before dilution and plating, the number of colonies recovered was further decreased, while the count of untreated bacteria remained almost constant. Suspensions with initial colony counts of $10^{7}$ bacteria/ml. and less did not show any growth (i.e. < ro bacteria/ml.), when subjected to one discharge and kept overnight at $4^{\circ}$. For $E$. coli B I 5 in tap water the microbicidal effects at the initial concentrations $2 \cdot 2 \times 10^{6}, 2 \cdot 2 \times 10^{7}$ and $2 \cdot 2 \times 10^{8}$ bacteria $/ \mathrm{ml}$. were $2 \cdot 4, \mathrm{I} \cdot 9$ and $0 \cdot 4$ l.p.d. respectively (Fig. 2). No protracted killing effect was observed when these suspensions were kept overnight in the refrigerator.

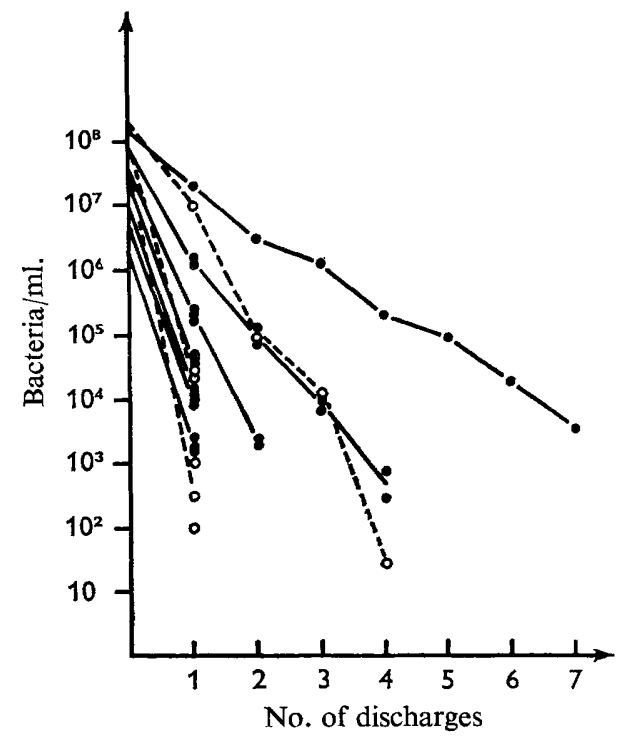

Fig. I

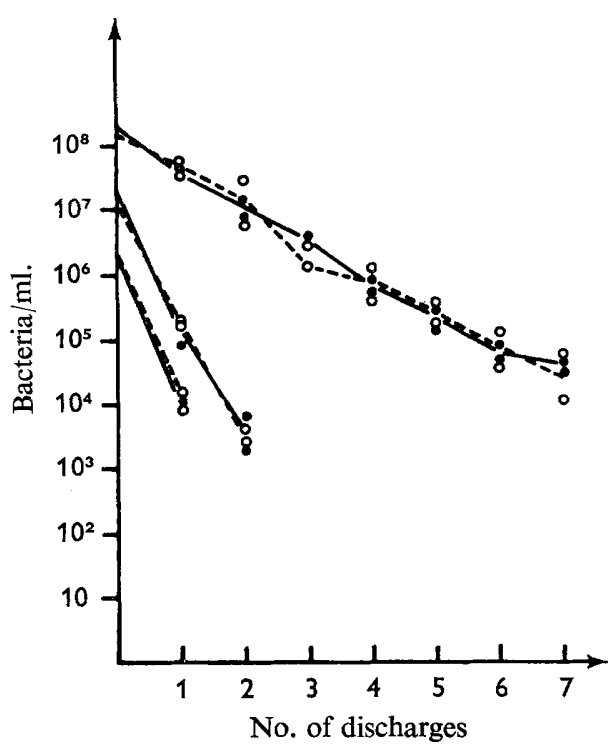

Fig. 2

Fig. I. Escherichia coli $\mathrm{B} 15$ suspended in $0.00 \mathrm{I} \mathrm{M}-\mathrm{KCl}$ and subjected to discharges (SEA and symbols, see Methods).

Fig. 2. Escherichia coli в I 5 suspended in tap water and subjected to discharges (SEA).

The microbicidal effect on Escherichia coli в I 7 suspended in $0.001 \mathrm{M}-\mathrm{KCl}$ at concentrations between $9.6 \times 10^{5}$ and $8.3 \times 10^{6}$ bacteria $/ \mathrm{ml}$. was 2.0 1.p.d. (Fig. 3). At moderately higher concentrations the inactivation was less but fairly constant in consecutive discharges. At an initial concentration higher than $10^{8}$ bacteria $/ \mathrm{ml}$. the killing curve deviated considerably from a straight line. The fourth and the fifth discharge had the greatest killing effect. The protracted killing effect achieved by keeping overnight in the refrigerator was, however, considerable also at high concentrations; only for initial concentrations above $10^{7}$ bacteria $/ \mathrm{ml}$. were the colony counts sufficiently high to allow an approximate estimation. In tap water at concentrations of $2 \cdot 7 \times 10^{6}$ and $2 \cdot 9 \times 10^{7}$ bacteria $/ \mathrm{ml}$. the bactericidal effect varied between $\mathrm{I} \cdot 6$ and $\mathrm{r} \cdot 2$ 1.p.d. (Fig. 4). At a concentration of $2 \cdot 5 \times 10^{8}$ bacteria $/ \mathrm{ml}$. it was decreased to about $0 \cdot 2$ 1.p.d. The protracted effect was generally negligible.

In these experiments the u.v.-sensitive B I5 strain of Escherichia coli was more strongly inactivated by discharges than the u.v.-resistant strain B 17. However, the 


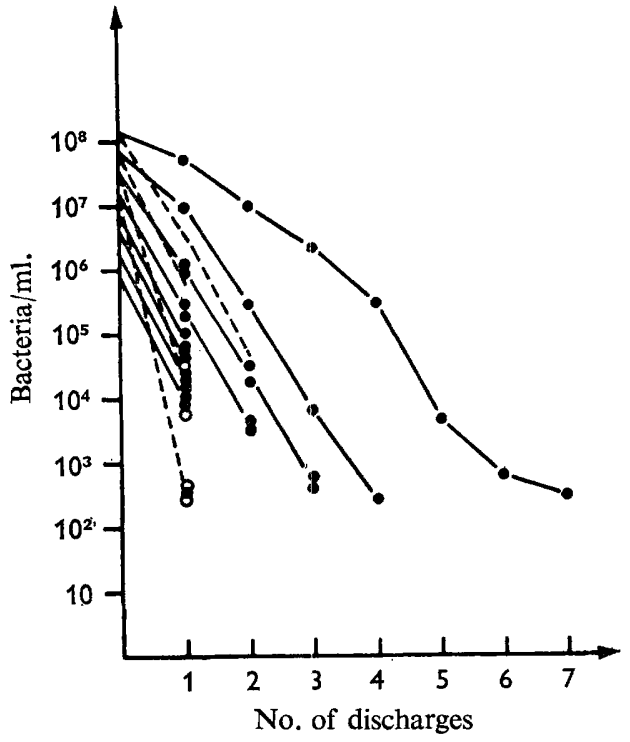

Fig. 3

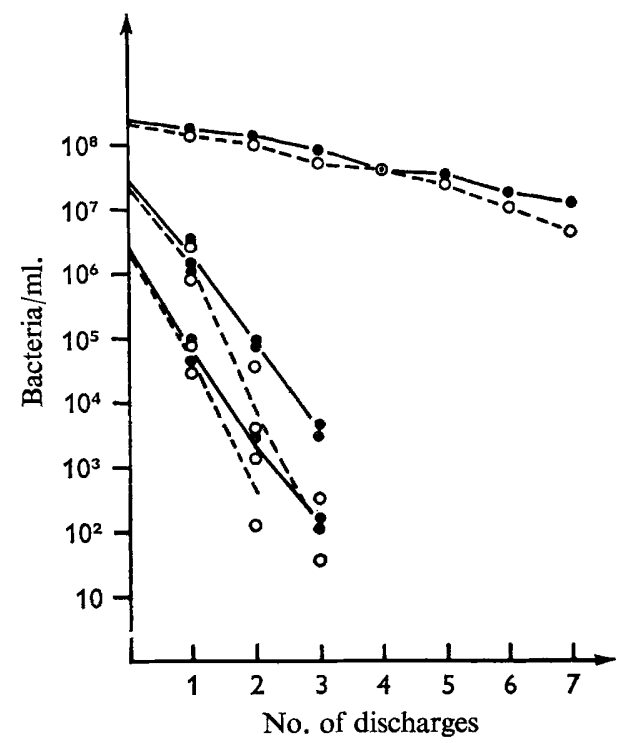

Fig. 4

Fig. 3. Escherichia coli в 17 suspended in $0.00 \mathrm{I} \mathrm{M}-\mathrm{KCl}$ and subjected to discharges (SEA).

Fig. 4. Escherichia coli $\mathbf{B}$ I7 suspended in tap water and subjected to discharges (SEA).

kinetics of the inactivation of strain B I 7 deviated considerably from that of continuous u.v. radiation.

The influence of albumin on the microbicidal effect

The presence of albumin at $100 \mathrm{mg} . / 1 .\left(\mathrm{A}_{260 \mathrm{m \mu}}=0.125\right)$ in a liquid containing Escherichia coli B I5 decreased the immediate killing effect of discharges slightly

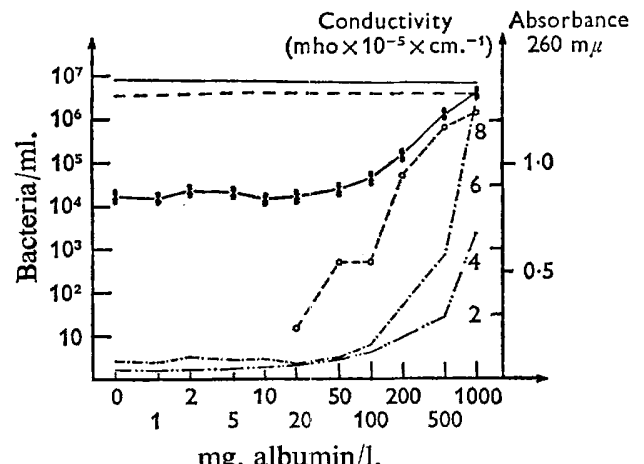

Fig. 5

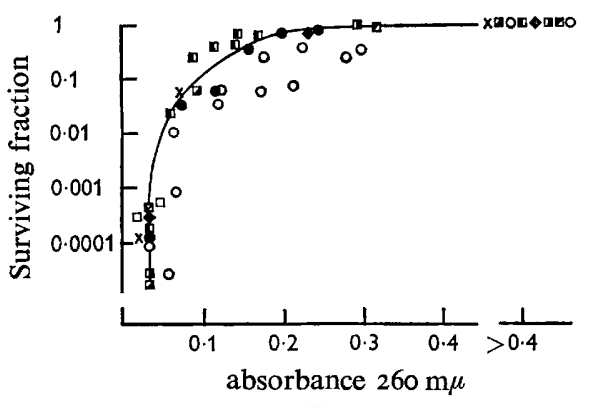

Fig. 6

Fig. 5. Escherichia coli B I5 suspended in different concentrations of albumin and subjected to one discharge (SEA). Upper horizontal lines represent viable counts of samples not subjected to discharges. - - - , Conductivity; - ..-, absorbance.

Fig. 6. The relation of the u.v.-absorbing capacity of the discharge liquid to the bactericidal effect on Escherichia coli BI7 enclosed in cellophan bags and immersed in the discharge liquids. SEA, two discharges. O, DNA; $\diamond$, RNA; $\times$, albumin; $\square$, dextran; $\mathbf{\square}$, blue dextran; $\square$, green dextran; $\mathbf{D}$, yellow dextran; $\mathbf{U}$, red dextran; $O$, yeast suspension. 
(Fig. 5); at higher concentrations the effect was gradually decreased. In suspensions containing albumin, I g./l., no bactericidal effect was observed. The protracted bactericidal effect was still more sensitive to albumin. No protracted effect could be demonstrated at concentrations $\geqslant 200 \mathrm{mg}$. $/ 1$.; at 50-100 mg./1., 98-99\% of the bacteria surviving immediately after the discharge were killed later, and at $20 \mathrm{mg} . / 1$. and below, $<10$ to 40 bacteria $/ \mathrm{ml}$. were recovered after keeping overnight in the refrigerator. These experiments showed that albumin decreased the immediate and the protracted killing effect. They did not show, however, whether this was due to protective action on the bacteria themselves or to a general neutralization of some physical or chemical activities of the discharges.

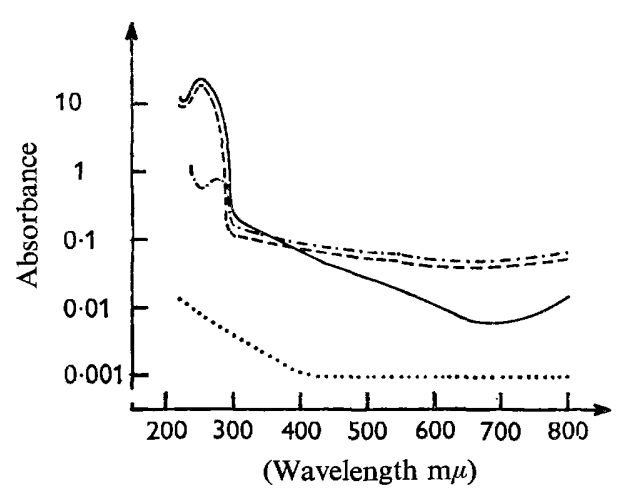

Fig. 7

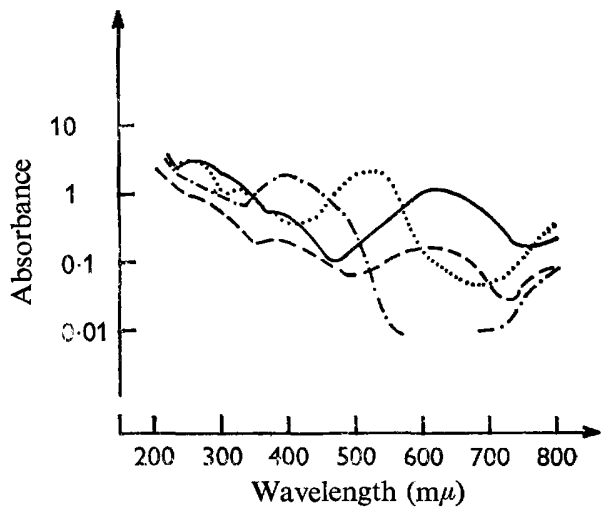

Fig. 8

Fig. 7. Absorbance of I g./l. solution of DNA (-), RNA (-- ), albumin (-.-)), and dextran $(\cdots)$.

Fig. 8. Absorbance of g./l. solution of variously coloured dextrans: (--), blue; (-- $)$, green; $(-\cdot-\cdot)$, yellow; $(\cdot \cdots)$, red.

The microbicidal effect on Escherichia coli suspensions enclosed in cellophan tubing immersed in discharge liquids containing light-absorbing substances

When cellophan tubing containing Escherichia coli B I 7 was placed on the bottom of the discharge vessel and two discharges made, the microbicidal effect was strongly influenced by the nature of the surrounding liquid (Fig. 6). Substances with high u.v. absorbing capacity, e.g. DNA, RNA, albumin (Fig. 7), decreased the microbicidal effect even at low concentrations; the nucleic acids were particularly active. Dextran at I g./l. influenced the bactericidal effect little (this solution had low u.v. absorbance); however, with a dextran concentration at Io g./1. the bactericidal effect was almost completely extinguished. This dextran solution (Io g./l) was viscous and the sound accompanying a discharge was weak, which might imply that the discharge itself was affected. Before the discharges all the dextran was not dissolved; after the discharges, however, no undissolved material remained. When solutions with chromophores chemically bound to the dextran molecules were used (substances provided by $\mathrm{AB}$ Pharmacia, Uppsala), the decrease of the killing effect was considerably greater. These substances showed a fairly strong absorption in the u.v. region (Fig. 8) which paralleled their decrease of the killing effect. No correlation with other parts of the spectrum was observed. 
The microbicidal effect on suspensions enclosed in cellophan tubing and placed at different distances from the spark

When a suspension of Escherichia coli strain B was enclosed in a cellophan tube and placed in a large discharge vessel (fig. 2 of Brandt et al. 1962) at different distances from the spark gap, the bactericidal effect became less at greater distances from the spark gap. At a distance of $8 \mathrm{~cm}$. one $45 \mathrm{kV}$. discharge decreased the colony count more than 300-fold; at distances more than $20 \mathrm{~cm}$. the killing effect was hardly measurable.

\section{The microbicidal effect of discharges in liquid and in air}

When different volumes of an Escherichia coli strain B 15 suspension were subjected to one discharge, the bactericidal effect was dependent on the volume (Fig. 9). The surviving fraction had a maximum at $600 \mathrm{ml}$., i.e. when the surface of the liquid was just below the electrodes so that the discharge took place in the air. In these experiments it should be observed that at the same spark gap (fig. I : 8, Edebo \& Selin, I968) the discharge voltage with electrodes in the air was higher than that with submerged electrodes.

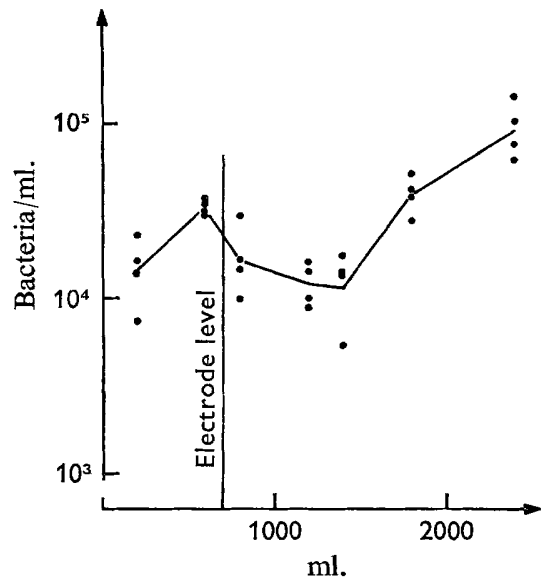

Fig. 9. The effect on different volumes of a suspension of Escherichia coli B 15 in tap water of discharges in the suspension $(>700 \mathrm{ml})$. and in the air above the suspension $(<700 \mathrm{ml}$.). One discharge. SEA except spark gap $=12 \mathrm{~mm}$. (i.e. $38 \mathrm{kV}$. with electrodes in water) and $s=12.9 \mathrm{~mm}$. No discharge $=1.6 \times 10^{5}$ bacteria $/ \mathrm{ml}$.

Cellophan tubing containing Escherichia coli B I 5 was placed on the bottom of the discharge vessel and at the same distance above the electrodes, and discharges were made with different volumes of tap water in the vessel, similar to the experiments described in Fig. 9. With no liquid and $600 \mathrm{ml}$. in the discharge vessel the discharge took place in the air, with 800 and $1200 \mathrm{ml}$. it occurred in the water. The cellophan tubes placed above the electrodes were surrounded by air. Except when no tap water was added the tubes below the electrodes were immersed in water. The colony counts of the samples kept in either medium were greatly decreased by discharges in water and in air. The greatest killing effect on the average was obtained with $600 \mathrm{ml}$. water in the discharge vessel. With regard to the original colony count the differences between the 
results with the different volumes were small. Therefore the efficiency of discharges in water and in air could not be adequately compared, since also reflexion, refraction and absorption of the radiation varied between different experiments, and at the same spark-gap a higher voltage was needed for discharges in air. Experiments where air was injected through the lower of two vertical electrodes while discharges were performed gave low bactericidal effects.

The microbicidal effect of submerged discharges with relatively low energy content $(91 \mathrm{~J}$.$) compared with discharges in air and continuous u . v$. radiation

The bactericidal effect of $620 \mathrm{~J}$. discharges did not show the typical u.v. inactivation curves on Escherichia coli BI7 (Figs. 3, 4). Therefore discharges with less energy

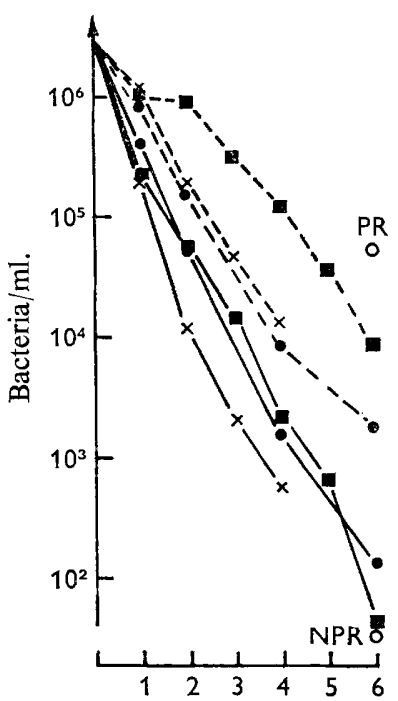

Fig. I0

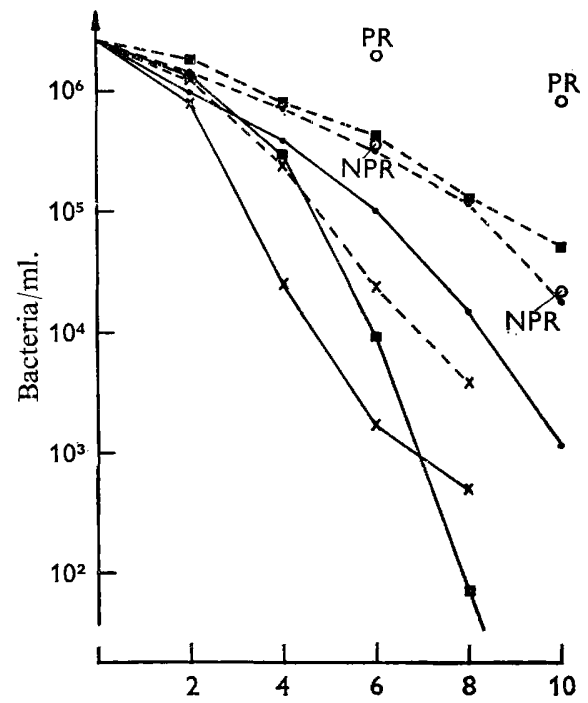

Fig. I I

Figs. I0, I I. Escherichia coli after treatment with submerged (1200 ml., - ) and air (200 ml., $\times$ ) discharges, and with continuous u.v. irradiation $(\mathbf{E})$. The units along the abscissa signify no. of discharges or min. u.v. treatment. Solid lines and NPR $=$ without photoreactivation $(\mathrm{PR})$, broken lines and $\mathrm{PR}=$ with $\mathrm{PR}$. $O$, bacteria enclosed in cellophan tubing. Fig. Io $=E$. coli strain в I 5 (u.v.-sensitive), Fig. I I $=E$. coli strain в I 7 (u.v.-resistant).

( $C=0.6 \mu \mathrm{F}$., $L=43 \mu \mathrm{H}$., spark gap $5 \mathrm{~mm}$., i.e. $\mathrm{I} 7.4 \mathrm{kV}$ with electrodes in water, $s=4.5 \mathrm{~mm}$., iron electrodes, 9I $\mathrm{J}$. per discharge) were used to compare the bactericidal effect of discharges in water and in air with that of continuous irradiation from an ordinary u.v. lamp (Philips TUV, $6 \mathrm{~W}$., $2537 \AA$., distance to sample $15 \mathrm{~cm}$.). The effect of submerged discharges was tested with $1200 \mathrm{ml}$. water and that of air discharges with $200 \mathrm{ml}$. water in the discharge vessel. In Figs. Io and II the units along the abscissa signify number of discharges or minutes of u.v. treatment. Due to few colonies viable counts $<$ IOO bacteria $/ \mathrm{ml}$. were not reliable. All the inactivation curves of $E$. coli strain B I 5 ran fairly close (Fig. IO); the general tendency was that they were slightly concave upwards. With the units chosen the inactivation by air discharges was somewhat greater; the energy content of the air discharges was greater and the volume treated smaller than that of submerged discharges. The curves for E. coli strain B I7 
(Fig. II) were more convex upwards and did not follow each other so closely. The B I 7 organisms were particularly sensitive to high doses of continuous u.v. radiation. The upward bend of the air-spark curve at low colony counts was presumably an artifact due to contamination from the part of the wall of the discharge vessel which had been located in the shadow.

\section{Photoreactivation}

Escherichia coli strains B I5 and B I 7 inactivated by submerged discharges were reactivated by illumination with visible light (Figs. IO, II). At comparable inactivation rates the magnitude of the reactivation of bacteria inactivated by discharges in the suspension was smaller than that of continuous u.v. irradiation and discharges in air. In contrast, bacteria inactivated by submerged discharges while enclosed in cellophan tubing were very liable to photoreactivation.

\section{DISCUSSION}

As a consequence of earlier results (Edebo \& Selin, 1968) experiments were designed to test the hypothesis that the electric arc used produced bactericidal quantities of u.v. radiation. Two different strains of Escherichia coli в were used: strain в I5 was u.v.-sensitive and strain B 17 was u.v.-resistant. When the bacteria were suspended in $0.00 \mathrm{I}$ M-KCl (Figs. I, 3) or tap water (Figs. 2, 4) at concentrations less than $2.5 \times 10^{7}$ bacteria/ml. the fraction of bacteria killed by one discharge was fairly constant. Strain B I 5 was more susceptible than was strain B I7. The bactericidal effect per discharge was decreased at higher concentrations of bacteria and when albumin was dissolved in the discharge medium (Fig. 5). It was also decreased for bacterial suspensions enclosed in cellophan tubing and immersed in the discharge liquids, when u.v.-absorbing material was present in the discharge medium (Fig. 6). Consequently the protective effect of these materials was not a result of intimate contact between bacteria and protective agent but a neutralization of something passing through the discharge medium. Most likely the neutralization was caused by absorption of u.v. radiation, as the extent of the neutralization paralleled u.v. absorbance, and u.v. radiation has a strong microbicidal effect. Since the distance between the electrodes and the cellophan tubes was $65-75 \mathrm{~mm}$., the radiation transmitted to the tubes with bacteria in a liquid with an absorbance $/ \mathrm{cm}$. (A/cm.) of 0.1 was $20 \%$ and in one of 0.2 it was $4 \%$ of that in $0.001 \mathrm{M}-\mathrm{KCl}$. In agreement with this were the results (Fig. 6) that the bactericidal effect was moderately decreased at $\mathrm{A} / \mathrm{cm}=0 \cdot \mathrm{I}$ and almost extinguished at $\mathrm{A} / \mathrm{cm}=0.2$. At the same absorbance coloured dextrans neutralized the bactericidal effect slightly more than the nucleic acids did; this might be due to their stronger absorption at wavelengths longer than $300 \mathrm{~m} \mu$. Also Saccharomyces cerevisiae suspended in the discharge medium decreased the bactericidal effect. At the same absorbance the decrease by yeast suspensions was less than that of u.v.-absorbing solutions. The absorbance values of the yeast suspensions were not quite comparable to the values of the solutions, however, since light scattering by the yeast particles contributed to the extinction measured in the spectrophotometer. In addition, suspensions of carbon and of calcium carbonate decreased the bactericidal effect. Experiments showing that the bactericidal effect was smaller at greater distances from the spark, and that the killing effect was transmitted through and generated in air (Fig. 9), also supported the initial hypothesis. 
However, the kinetics of the inactivation by discharges with an energy content of 620 J. (Figs. 3, 4) did not show the characteristics of u.v.-killing for Escherichia coli strain B I 7. Assume that more than one u.v. quantum hit was necessary to kill a B I 7 bacterium, and that some bacteria were always protected from direct u.v. radiation by the shadow cast by the nylon insulation of the electrodes. When the intensity of the radiation was very strong, almost all bacteria outside the shadow should have been killed. At the next discharge the process was repeated and as the discharge also brought about good mixing of the suspension a nearly straight inactivation curve should result. Since the u.v. radiation probably was very strong with $620 \mathrm{~J}$. per discharge, the generally straight inactivation curves at this energy content (Figs. 3, 4) agreed with u.v. killing, although they did not show the usual u.v. inactivation kinetics. However, since the inactivation of u.v.-sensitive strain B I5 (Figs. I, 2) exceeded that of u.v.-resistant strain B I7 (Figs. 3, 4) there could not be a well-defined shadow. The size of the arc, reflexion against the walls of the discharge vessel, and the presence of high concentrations of bacteria contribute to make the shadow less absolute. At lower energies (9I J.; Fig. I I), where the light intensity was less, the inactivation kinetics of discharges were more like those of continuous u.v. radiation.

Rentschler, Nagy \& Mouromseff (I94I) found that the same dose of u.v. radiation $(2537 \AA)$ given in periods ranging from a few microseconds to several hours yielded the same bactericidal effect, provided that the time of treatment did not involve an appreciable part of the life-cycle of the organism under exposure. Marcovich (1956), who studied the induction of Escherichia coli $\mathrm{K}$ I $2(\lambda)$ by u.v. radiation showed that the same dose given in 0.1 or 10,000 sec. had the same effect. In most biological systems the surviving fraction of a given dose is independent of the intensity of the incident radiation (Zelle \& Hollaender, 1955). Consequently, the yield of active photons from the arc should be decisive for the microbicidal effect. One may, however, expect different kinds of cell damage by the different wavelengths (Zelle \& Hollaender, I955) which seem to be produced by discharges.

The biological effect of u.v. radiation is dependent on several mechanisms. A large proportion of the effect is caused by thymine dimerization in DNA. Cross-linking between DNA and messenger RNA or DNA and protein may also occur (Wacker, I963; McLaren \& Shugar, I964). Another mechanism has been postulated (Witkin I964). Radiation-resistant Escherichia coli в strains are probably capable of repairing or getting around the dimer blocks, whereas sensitive bacteria are not (Setlow, Swenson $\&$ Carrier, I963). The repair processes are enhanced by 3000-5000 $\AA$ radiation which is called photoreactivation (PR). Two kinds of PR have been described, one of which is almost independent of the dose rate during the PR treatment (Jagger \& Stafford, 1965). Assume that the smaller PR of bacteria inactivated by submerged discharges (Figs. IO, I I) was due to the fact that some PR did already take place during the discharge. If this were the case, this mechanism would be still more pronounced with bacteria in cellophan tubing, since, due to preferential absorption of light of shorter wavelengths by the water and the wall of the tube, the proportion of light of longer wavelengths was greater. Since the PR of bacteria inactivated in cellophan tubes often was even greater than that after continuous far ultraviolet $(2537 \AA)$ inactivation (Figs. IO, I I), the PR by discharges was probably of little importance.

Consider also the possibility that the smaller PR after submerged discharges was a consequence of uneven distribution of microbicidal photons in the suspension. Under 
such conditions bacteria close to the spark might be hit so heavily that they could not be photoreactivated, and some bacteria would not be hit at all. Due to stirring of the suspension by each discharge the number of hits on each bacterium should be more nearly equal after several discharges. The relation between the u.v. radiation dose required for killing a certain fraction of the bacteria without and with PR may be expressed as the dose-reduction factor which in some systems is constant (Rupert, 1964). When Escherichia coli strain B I7 was inactivated by u.v. irradiation this factor was not constant but moderately decreasing at higher inactivation rates, being 0.5 at Io min of u.v. treatment. At inactivation by discharges the factor was moderately increasing, being 0.8 at Io discharges (Fig. II). Since the number of photon hits on individual bacteria was more nearly equal after several discharges, these observations suggest that further microbicidal mechanisms, not subject to photoreactivation, exist. The observation that the bactericidal effect on bacteria suspended in $0.00 \mathrm{I} \mathrm{M}-\mathrm{KCl}$ and subjected to one discharge was increased on standing in the refrigerator overnight (Figs. I, 3), showed that at least under such conditions photon radiation was not the only killing mechanism.

This work was made possible by grants from the Swedish Technical Research Council and from Grängesbergsbolaget, Sweden. The technical assistance provided by Mrs Mona Åkesson and Miss Lillemor Svensk is gratefully acknowledged.

\section{REFERENCES}

Allen, M. \& SoIKe, K. (1966). Sterilization by electrohydraulic treatment. Science, N. Y. x54, I 55.

Brandt, B., Edebo, L., Hedén, C.-G., Hjortzberg-Nordlund, B., Selin, I., \& Tigerschöld, M. (1962). The effect of submerged electrical discharges on bacteria. $T V F$ 39, 222.

EDEBO, L. \& Selin, I. (1968). The effect of the pressure shock wave and some electrical quantities in the microbicidal effect of transient electric arcs in aqueous systems. J. gen. Microbiol. 50, 253.

JAGGER, J. \& STAFFORD, R. S. (I965). Evidence for two mechanisms of photoreactivation in Escherichia coli в. Biophys. $J .5,75$.

MARCOVICH, H. (I956). Etude sur l'action des rayons ultraviolets sur les systèms lysogène Escherichia coli $\mathrm{K}$ I $2(\lambda)$, K I $2 \mathrm{~S}, \lambda$. Annls Inst. Pasteur 9I, $5 \mathrm{I}$ I.

Mclaren, A. D. \& Shugar, D. (1964). Photochemistry of Proteins and Nucleic Acids. Oxford: Pergamon Press.

RentsChler, H. C., NAGY, R. \& MOUROMSEFF, G. (I94I). Bactericidal effect of ultraviolet radiation. J. Bact. 4r, 745 .

RuPERT, C. S. (1964). Photoreactivation of ultraviolet damage. In Photophysiology. Ed. by A. C. Giese. p. 283. New York: Acacemic Press.

Setlow, R. B., Swenson, P. A. \& CARrIER, W. L. (1963). Thymine dimers and inhibition of DNA synthesis by ultraviolet irradiation of cells. Science, N.Y. 142, 1464 .

WaCKer, A. (1963). Molecular mechanisms of radiation effects. Progr. Nucleic Acid Res. I, 369.

WitKIN, E. (I964). Photoreversal and 'dark repair' of mutations to prototrophy induced by ultraviolet light in photoreactivable and non-photoreactivable strains of Escherichia coli. Mutation Res. $\mathbf{1}, 22$.

Zelle, M. R. \& Hollaender, A. (1955). Effects of radiation on bacteria. In Radiation Biology. Ed by A. Hollaender. Vol. 2, p. 365. New York: McGraw-Hill. 